\title{
PENGARUH RASIO KEUANGAN TERHADAP KINERJA PERUSAHAAN MANUFAKTUR YANG TERDAFTAR DI BURSA EFEK INDONESIA (SEKTOR CONSUMER GOODS INDUSTRY)
}

\author{
Rizka Hadya \\ Program Studi Manajemen, Universitas Ekasakti \\ rizkahadya@gmail.com
}

\begin{abstract}
This research as a purpose to know what influence of liquidity ratio solvency ratio for profitability ratio. This research was conducted on the consumer goods industrycompanies in Indonesia Stock Exchange (IDX). The data used are secondary data from company financial statements of consumer goods industry. The population in this study is a consumer goods industryand sample period 20132017 and used a total of 7 samples from 32 companies. The technique of taking the sample using purposive sampling method The data analysis technique used multiple linear regression analysis using Eviews. The results showed that the variable, Liquidity, Solvency has a positive and significant impact on profitability ( ROE)
\end{abstract}

Keywords: Liquidity, Solvency, Profitability.

\section{PENDAHULUAN}

Analisa rasio keuangan merupakan instrumen analisa perusahaan yang ditujukan untuk menunjukkan perubahan dalam kondisi keuangan perusahaan yang bersangkutan. Dengan analisa rasio keuangan ini dapat diketahui kekuatan dan kelemahan perusahaan di bidang keuangan.

Kasmir (2009) membagi rasio keuangan menjadi tiga macam yang berbeda yaitu : rasio likuditas, solvabilitas, dan profitabilitas. Likuiditas adalah kemampuan perusahaan dalam memnuhi kewajiban yang sudah jatuh tempo. Solvabilitas dimaksudkan untuk mengukur sejauh mana aktiva perusahaan dibiayai dengan utang. Aktivitas untuk mengukur efektivitas perusahaan dalam menggunakan aktiva yang dimilikinya. Rasio profitabilitas menunjukkan kemampuan perusahaan dalam mencari keuntungan
Analisis rasio keuangan dipakai sebagai sistim peringatan awal (Early Warning System) terhadap kemunduran kondisi keuangan dari suatu perusahaan. Analisis rasio dapat membimbing investor membuat keputusan atau pertimbangan tentang apa yang akan dicapai oleh perusahaan dan atau bagaimana prospek yang akan dihadapi dimasa yang akan datang. Sesuai dengan beragam jenis kegunaan informasi akuntansi, maka jenis-jenis rasio laporan keuangan yang digunakan oleh si pengambil keputusan tergantung pada jenis keputusan yang akan dibuat dan metode pengambilan keputusan yang digunakan (Dewanti,2010).

Beberapa penelitian terdahulu tentang analisis laporan keuangan telah banyak dilakukan, Nidya Afrinda (2013) melakukan penelitian dengan judul "Analisis Pengaruh Likuiditas dan Solvabilitas Terhadap Profitabilitas pada Perusahaan 
Makanan dan Minuman yang Terdaftar di Bursa Efek Indonesia (BEI)". Dengan hasil penelitian bahwa Current Ratio, Cash Ratio, Quick Ratio, Debt to Total Asset Ratio, Debt to total Equity Ratio dan Long Term to Equity Ratio secara simultan berpengaruh signifikan terhadap variabel Profitabilitas (ROA) Perusahaan Makanan dan Minuman yang terdaftar di Bursa Efek Indonesia (BEI) periode 20062012.

Rina Selva Johan(2012) menunjukkan bahwa secara simultan likuiditas dan solvabilitas berpengaruh secara signifikan terhadap profitabilitas, secara parsial likuiditas tidak berpengaruh signifikan terhadap profitabilitas dan secara parsial solvabilitas berpengaruh signifikan terhadap profitabilitas.

Penelitian ini berbeda dengan penelitian sebelumnya, karena pada penelitian kali ini akan meneliti pengaruh likuiditas dan solvabilitas terhadap profitabilitas pada perusahaan Makanan dan Minuman yang terdaftar di BEI periode 20132017. Penelitian ini dimaksudkan untuk melakukan pengujian yang lebih lanjut temuan-temuan empiris mengenai rasio keuangan, khususnya yang menyangkut likuiditas, solvabilitas dan profitabilitas perusahaan.

\section{LANDASAN TEORI DAN HIPOTESIS}

Kinerja keuangan merupakan gambaran kondisi keuangan perusahaan pada suatu periode tertentu menyangkut aspek penghimpunan dana maupun penyaluran dana, yang biasanya diukur dengan indikator kecukupan modal, likuiditas, dan profitabilitas (Jumingan, 2006).
Menurut Hadi Tjokrosusilo (2011) ada sejumlah indikator bahwa suatu perusahaan sehat, yaitu Jumlah pelanggan, Efektifitas karyawan, Jumlah cabang, Asset, Revenue/Profit, Produk principal bertambah lebih cepat dari industri, dan Memikirkan karyawan (People Development).

Pengertian analisa rasio keuangan menurut James $\mathrm{C}$ van Horne dalam buku Kasmir (2010:104) adalah indeks yang menghubungkan dua angka akuntansi dan diperoleh dengan membagi satu angka dengan angka lainnya. Rasio yang umum digunakan adalah rasio likuiditas, solvabilitas dan profitabilitas.

Rasio likuiditas merupakan rasio untuk mengukur kemampuan dalam memenuhi kewajiban jangka pendeknya pada saat ditagih oleh suatu perusahaan. Rasio likuiditas terdiri dari rasio lancar (Current Ratio), rasio cepat (quick ratio), rasio kas (cash ratio) dan inventory to net working capital (Kasmir,2013: 134142).

Menurut Kasmir (2010:151) rasio solvabilitas atau leverage ratio merupakan rasio yang digunakan untuk mengukur sejauh mana aktiva perusahaan dibiayai dengan utang. Rasio solvabilitas terdiri dari rasio hutang terhadap total aktiva (debt to assets ratio), rasio hutang terhadap ekuitas (debt to equity ratio) dan longterm debt to equity ratio.

Rasio profitabilitas atau sering disebut Rentabilitas suatu perusahaan menunjukkan kemampuan suatu perusahaan untuk menghasilkan laba dengan modal yang ditanamkan di dalam perusahaan tersebut. Rasio profitabilitas terdiri dari net profit margin, hasil pengembalian investasi (return on investment) dan hasil 
pengembalian ekuitas (return on equity).

\section{Pengaruh Likuiditas terhadap Profitabilitas}

Rasio likuiditas merupakan rasio untuk mengukur kemampuan dalam memenuhi kewajiban jangka pendeknya pada saat ditagih oleh suatu perusahaan (Kasmir, 2013). Profitabilitas adalah kemampuan perusahaan untuk memperoleh keuntungan dari usahanya (Danang Sunyoto, 2013). Hubungan antara likuiditas dan profitabilitas adalah jika kemampuan sebuah perusahaan tersebut dalam membayar kewajiban jangka pendeknya baik, maka kemampuan dalam menghasilkan labanya pun baik.

Penelitian tentang variabel yang berpengaruh terhadap profitabilitas dilakukan oleh Ermadiani dan Andriyanto (2002) dapat diketahui ada pengaruh antara likuiditas terhadap profitabilitas. Hal ini meirunjukkan perubahan dalam likuiditas berpengaruh terhadap perubahan dalam profitabilitas. Penelitian ini menguatkan Ermaidiani dan Andriyanto (2002) dan Aminatuzzahra (2010), karena samasama menunjukkan adanya pengaruh yang positif dari current ratio terhadap profitabilitas.

Hal ini berbanding terbalik dengan penelitian Hastuti (2010) menunjukkan adanya pengaruh negatif dari likuidias terhadap profitabilitas. Artinya, apabila terdapat peningkatan rasio larrcar dengan anggapan variabel konstan, maka akan diikuti dengan penurunan profitabilitas.

Dari uraian di atas, dapat dikembangkan hipotesis pertama sebagai berikut: Rasio Likuiditas berpengaruh signifikan terhadap

\section{kinerja keuangan (diproxy oleh rasio profitabilitas) pada perusahaan manufaktur yang terdaftar di Bursa Efek Indonesia.}

\section{Pengaruh Solvabilitas terhadap Profitabilitas}

Menurut Kasmir (2010:151) rasio solvabilitas atau leverage ratio merupakan rasio yang digunakan untuk mengukur sejauh mana aktiva perusahaan dibiayai dengan utang. Profitabilitas adalah kemampuan perusahaan untuk memperoleh keuntungan dari usahanya (Danang Sunyoto, 2013). Kedua rasio tersebut sangat berhubungan karena jika perusahaan tersebut mampu membayar hutang jangka panjangnya, maka perusahaan tersebut termasuk kepada perusahaan yang baik dalam menghasilkan laba.

Gryglewicz (2010) yang mengkaji dampak baik likuiditas dan kekhawatiran solvabilitas pada perusahaan pembiayaan, menunjukkan hasil adanya interaksi dalam kebijakan kas yang dinamis di mana cadangan kas akan meningkatan profitabilitas dan berkorelasi positif dengan arus kas, dan menemukan adanya kekhawatiran bahwa likuiditas menyebabkan penurunan dispersi spread kredit.

Hasil penelitian lainnya yang menunjukkan adanya pengaruh leverage terhadap profitabilitas dilakukan oleh Aminatuzzahra (2009) yang menunjukkan bahwa solvabilitas berpengaruh terhadap profitabilitas.

Bertentangan dengan penelitian Hastuti (2010) juga menunjukkan adanya pengaruh solvabilitas terhadap profitabilitas. Pengaruh yang terjadi adalah pengaruh negatif, artinya peningkatan hutang 
perusahaan bisa berpengaruh terhadap penurunan keuntungan perusahaan.

Dari uraian di atas, dapat dikembangkan hipotesis kedua sebagai berikut: Rasio Solvabilitas berpengaruh signifikan terhadap kinerja keuangan (diproxy oleh rasio profitabilitas) perusahaan manufaktur yang terdaftar di Bursa Efek Indonesia.

\section{METODE PENELITIAN}

Jenis penelitian yang ada dalam penelitian ini adalah penelitian kuantitatif, yaitu data penelitian yang berbentuk angka atau data kualitatif yang diangkakan atau skoring (Sugiyono, 2008:23). Penelitian kuantitatif adalah pendekatan ilmiah terhadap pengambilan keputusan manajerial dan ekonomi (Kuncoro, 2011). Penelitian ini dilakukan dengan menggunakan penelitian kuantitatif karena penelitian ini bersifat menganalisa laporan keuangan Perusahaan Sektor Telekomunikasi yang Terdaftar di Bursa Efek Indonesia dan menafsirkan hasilnya dalam bentuk angka-angka.

Menurut Cooper (2008:374)

menerangkan populasi adalah sekelompok dari elemen-elemen yang ingin disimpulkan. Populasi pada penelitian ini adalah perusahaan manufaktur sektor consumer goods industry yang terdaftar di Bursa Efek Indonesia sebanyak 32 perusahaan. Sedangkan sampel adalah kelompok kasus, partisipan, kejadian, atau bukti yang terdiri atas target populasi, yang dipilih secara hati-hati untuk merepresentasikan populasi Cooper (2008:711).

Sampel pada penelitian ini dipilih berdasarkan teknik pengumpulan sampel purposive sampling di mana penelitian ini tidak dilakukan pada seluruh populasi, tapi terfokus pada target dengan mempertimbangkan kriteria-kriteria tertentu yang telah dibuat terhadap objek yang sesuai dengan tujuan penelitian, dalam hal ini penelitian dilakukan pada perusahaan-perusahaan yang terdaftar di Bursa Efek Indonesia. Kriteria-kriteria tertentu yang telah dibuat oleh peneliti terhadap objek dalam penelitian ini adalah sebagai berikut: (1)Perusahaan-perusahaan yang terdaftar di Bursa Efek Indonesia periode tahun 20132017.(2)Perusahaan berada pada sektor consumer goods industry.(3)Perusahaan yang menerbitkan laporan keuangan secara periodik dan lengkap dari tahun 2013-2017.(4)Perusahaan yang memiliki likuiditas,solvabilitas, profitabilitas positif sepanjang periode 2013-2017

Dari kriteria di atas,maka diperoleh data sebagai sampel penelitian sebanyak 7 perusahaan manufaktur sektor consumer goods industry, atau sebanyak 35 observasi. 
Tabel 1

Definisi Operasional Variabel

\begin{tabular}{|c|c|c|c|}
\hline No & Variabel & Definisi & Pengukuran \\
\hline 1 & Likuiditas & $\begin{array}{l}\text { Merupakan rasio yang } \\
\text { digunakan untuk } \\
\text { membandingkan } \\
\text { antara jumlah aset } \\
\text { lancar dikurangi } \\
\text { dengan inventory dan } \\
\text { dibagi dengan jumlah } \\
\text { hutang lancar. }\end{array}$ & $\mathrm{QR}=\frac{\text { Aset Lancar }- \text { Inv. }}{\text { Hutang Lancar }} \times 100 \%$ \\
\hline 2 & Solvabilitas & $\begin{array}{l}\text { Merupakan rasio yang } \\
\text { digunakan untuk } \\
\text { membandingkan } \\
\text { antara jumlah seluruh } \\
\text { hutang dan dibagi } \\
\text { dengan jumlah seluruh } \\
\text { aset. }\end{array}$ & $\mathrm{DAR}=\frac{\text { Total Hutang }}{\text { Total Aset }} \times 100 \%$ \\
\hline 3 & Profitabilitas & $\begin{array}{l}\text { Merupakan rasio yang } \\
\text { digunakan untuk } \\
\text { membandingkan } \\
\text { antara jumlah laba } \\
\text { bersih setelah pajak } \\
\text { dan dibagi dengan } \\
\text { jumlah modal sendiri }\end{array}$ & $\mathrm{ROE}=\frac{\mathrm{EAT}}{\text { Modal Sendiri }} \times 100 \%$ \\
\hline
\end{tabular}

Penelitian ini menggunakan pendekatan kuantitatif, dengan alat yang digunakan dalam penelitian ini adalah analisis regresi linear berganda. Sebelum melakukan estimasi dengan menggunakan pengujian stasioner yang bertujuan untuk mengetahui stasioner atau tidaknya data penelitian. Setelah melakukan pengujian stasioneritas, analisis data menggunakann uji asumsi klasik yang terdiri dari uji normalitas data, uji multikolinieritas, uji heterokedastisitas dan uji otokorelasi. Rumus persamaan uji regresi berganda adalah sebagai berikut:

Profitability $=\alpha+\beta_{1} L i q+\beta_{2} S o l v+e$

Keterangan:

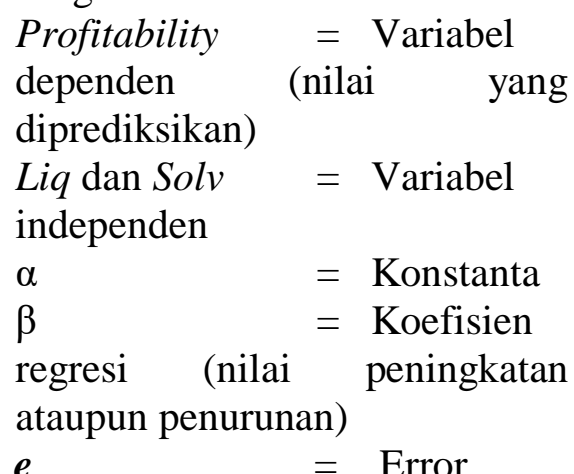




\section{HASIL DAN PEMBAHASAN}

Tabel 2

Hasil Uji Regresi Linear Berganda

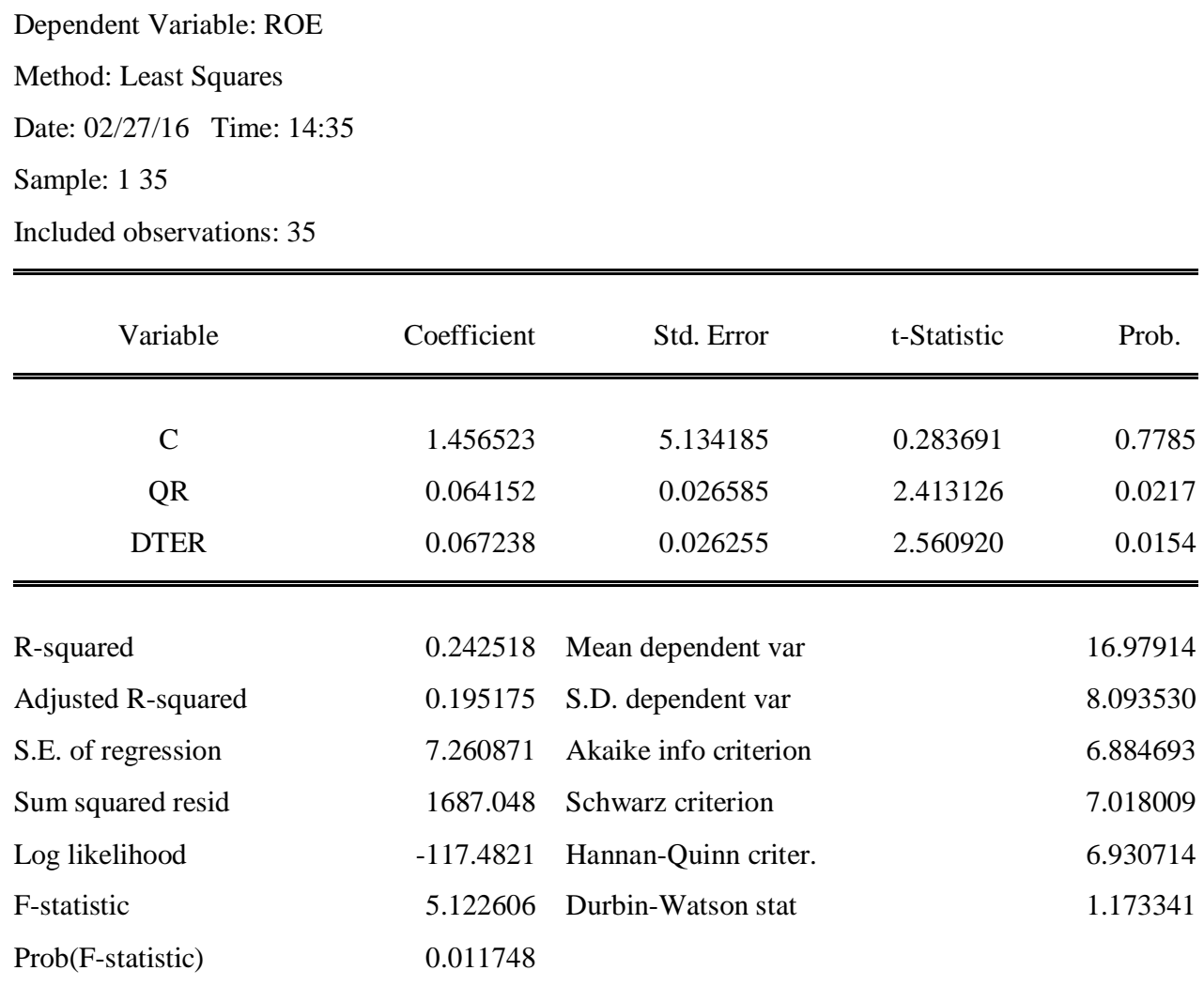

Sumber : Data Eviews

\section{Pengaruh Likuiditas terhadap Profitabilitas}

Dari tabel di atas diketahui bahwa nilai $\alpha$ sebesar 1,456523 dan nilai $\beta$ sebesar 0,064152. Secara determinan (R-Squared), likuiditas mempengaruhi profitabilitas sebesar 0,087274 dan selebihnya dipengaruhi oleh faktor lain.

Pada tabel tersebut dihasilkan nilai koefisien regresi untuk variabel Likuiditas yang diproxy oleh (Quick Ratio) sebesar 0,064152 bertanda positif dengan nilai probabilita $0,0217<0,05$ yang berarti bahwa Quick Ratio mempunyai pengaruh positif yang signifikan terhadap
Profitabilitas yang diproxy oleh (Return On Equity). Dengan demikian dapat disimpulkan hipotesis pertama diterima.

Ermadiani dan Andriyanto (2002) dapat diketahui ada pengaruh antara likuiditas terhadap profitabilitas. Hal ini meirunjukkan perubahan dalam likuiditas berpengaruh terhadap perubahan dalam profitabilitas. Penelitian ini menguatkan Ermaidiani dan Andriyanto (2002) dan Aminatuzzahra (2010), karena samasama menunjukkan adanya pengaruh yang positif dari current ratio terhadap profitabilitas. 
Hasil penelitian ini sama dengan penelitian yang dilakukan oleh $\mathrm{M}$. Khafidz Mansur (2015) yang menemukan bahwa Likuiditas berpengaruh positif tetapi tidak signifikan terhadap profitabilitas. Hubungan yang positif antara QR dengan ROE pada penelitian ini mempunyai arti bahwa kenaikan likuiditas akan diikuti oleh kenaikan profitabilitas perusahaan.

Penelitian ini mempunyai kesamaan hasil dengan penelitian yang dilakukan oleh Romdayanah (2011) dimana likuiditas berpengaruh positif dan tidak signifikan terhadap profitabilitas bank syari'ah.

Penelitian ini juga didukung oleh penelitian yang dilakukan Erma Risdo Tohonan,dkk (2012) yang menemukan bahwa secara parsial likuiditas tidak berpengaruh signifikan terhadap profitabilitas.

\section{Pengaruh Solvabilitas terhadap Profitabilitas}

Tabel 2 menunjukkan bahwa nilai kontanta sebesar 1,456523 dan nilai $\beta$ sebesar 0,067238. Secara determinan (R-Squared), likuiditas mempengaruhi profitabilitas sebesar $0,1046 \%$ dan selebihnya dipengaruhi oleh faktor lain.

Pada tabel tersebut dihasilkan nilai koefisien regresi untuk variabel Solvabilitas yang diproxy oleh (Debt to Equity Ratio) sebesar 0,067238 bertanda positif dengan nilai probabilita $0.0154<0,05$ yang berarti bahwa solvabilitas mempunyai pengaruh positif yang signifikan terhadap Profitabilitas yang diproxy oleh (Return On Equity) . Dengan demikian dapat disimpulkan hipotesis kedua diterima.

Erma Risdo Tohonan,dkk (2012) menunjukkan bahwa secara parsial secara parsial solvabilitas berpengaruh signifikan terhadap profitabilitas. Hal ini disebabkan karena terlalu banyak hutang yang dibayarkan perusahaan sehingga resiko financial yang ditanggung perusahaan juga akan semakin besar begitu juga sebaliknya semakin rendah rasio ini maka profitabillitas perusahaan akan meningkat (Syamsudin,2001).

Sejalan dengan penelitian ini, penelitian dari Ruzaini Abdi Laksono (2013) menemukan bahwa Secara parsial solvabilitas berpengaruh positif dan signifikan terhadap rentabilitas (profitabilitas).

Erma Risdo Tohonan,dkk (2012) menunjukkan bahwa secara parsial secara parsial solvabilitas berpengaruh signifikan terhadap profitabilitas. Hal ini disebabkan karena terlalu banyak hutang yang dibayarkan perusahaan sehingga resiko financial yang ditanggung perusahaan juga akan semakin besar begitu juga sebaliknya semakin rendah rasio ini maka profitabillitas perusahaan akan meningkat (Syamsudin,2001). Sejalan dengan penelitian ini.

penelitian dari Ruzaini Abdi Laksono (2013) menemukan bahwa Secara parsial solvabilitas berpengaruh positif dan signifikan terhadap rentabilitas (profitabilitas). Hasil penelitian ini sesuai dengan penelitian Hastuti (2010) yang menunjukkan adanya pengaruh negatif dari rasio solvabilitas terhadap profitabilitas.

\section{KESIMPULAN DAN SARAN Kesimpulan}

Rasio Likuiditas yang diproxy oleh Quick Ratio mempunyai pengaruh positif yang signifikan terhadap profitabilitas yang diproxy oleh Return on Equity yang ditunjukkan 
dengan nilai probabilitas lebih besar dari 0,05 yaitu lebih kecil 0.0217

Rasio Solvabilitas yang diproxy oleh Debt to Equity Ratio mempunyai pengaruh positif yang signifikan terhadap profitabilitas yang diproxy oleh Return on Equity yang ditunjukkan dengan nilai probabilitas lebih kecil dari 0,05 yaitu sebesar 0.0154

\section{Saran}

Perusahaan dapat memperbaiki kinerja keuangannya secara parsial melalui Peningkatan likuiditas (current ratio), mengurangi rasio hutang (Debt to equity ratio)

Bagi Manajemen, dalam rangka meningkatkan profitabilitas perusahaan, pihak manajemen harus memperhitungkan komposisikomposisi Debt to Equity Ratio. Karena rasio tersebut dapat digunakan oleh para investor sebagai pertimbangan sebelum melakukan investasi pada perusahaan. Karena apabila rasio tersebut dalam kondisi optimal, maka kinerja operasional dan profitabilitas akan meningkat.

Bagi Para Investor, perusahaan yang baik adalah perusahaan yang mampu menghasilkan profit besar, jika modal lebih besar atau dibawah $100 \%$, berarti sebagian besar biaya aktiva tetap dibiayai oleh modal dan tingkat resiko keamanan usaha semakin kecil dalam jangka panjang., Sehingga investor sebaiknya juga melihat perusahaan dari rasio tersebut, karena mengindikasikan kinerja perusahaan. Profit merupakan cerminan dari kinerja perusahaan, maka dari itu investor dan manajer hendaknya mempertimbangkan informasi yang terkait dengan kinerja keuangan perusahaan terutama Debt to Equity Ratio yang berpengaruh pada peningkatan profit.
Bagi peneliti selanjutnya, diharapkan melakukan penelitian lanjutan dengan memperluas sampel dan data penelitian. Misalnya dengan menggunakan periode pengamatan yang lebih panjang serta menambahkan variabel independen lain yang diduga mempengaruhi profitabilitas.

\section{DAFTAR PUSTAKA}

Afriyeni, Endang. 2008.Penilaian Analisis Kinerja Dengan Menggunakan Analisis Rasio.Jurnal Ekonomi dan Bisnis. Vol 3 No 2.

Danil, A., \& Yusra, I. (2019). Pengaruh kausal antara ukuran perusahaan, nilai buku dan likuiditas saham di Bursa Efek Indonesia. INA-Rxiv.

Hadya, R. (2014a). Analisis likuiditas, solvabilitas, nilai pasar dan return saham: studi empiris pada perusahaan sektor perbankan yang terdaftar di Bursa Efek Indonesia. Jurnal Riset Manajemen Dan Akuntansi, 3(1), 107-118.

Hadya, R., Begawati, N., \& Yusra, I. (2017). Analisis Efektivitas Pengendalian Biaya, Perputaran Modal Kerja, dan Rentabilitas Ekonomi Menggunakan Regresi Data Panel. Jurnal Pundi, 01(03), 1-35.

Hamidu, Novia. 2013.Pengaruh Kinerja Keuangan Terhadap Pertumbuhan Laba Pada Perbankan di BEI. Jurnal EMBA. Vol.1 
No.3 Juni 2013, Hal. 711721.

Hanafi, D., \& Yusra, I. (2019). Tangibility, liquidity, growth opportunity, dan leverage: studi pada perusahaan terdaftar di Bursa Efek Indonesia. INA-Rxiv, (2001).

Kasmir. 2013. Analisis Laporan Keuangan.Jakarta: PT. Raja Grafindo Persada.

Kurniawan, A., \& Yusra, I. (2019). Apakah profitabilitas dan nilai buku berdampak terhadap return saham?: studi empiris pada perusahaan LQ45. INA-Rxiv.

Mulfita, A., \& Yusra, I. (2019). Analisis regresi data panel terhadap likuiditas saham di Indonesia. INA-Rxiv.

Putra, A. D., \& Yusra, I. (2019). Peran profitabilitas dalam memoderasi pengaruh free cash flow terhadap kebijakan dividen di Indonesia. INA-Rxiv.

Putra, I., \& Yusra, I. (2019). Analisis likuiditas saham menggunakan regresi data panel. INA-Rxiv.

Qusibah, V. L., \& Yusra, I. (2019). Profitabilitas , dan Ukuran Perusahaan Sebagai Faktor Penentu Leverage Perusahaan Di Indonesia. Jurnal Pundi, 03(01), 13-26. https://doi.org/10.31575/jp.v3i1. 125

Sari, N. N., \& Yusra, I. (2018). Analisis Likuiditas, Leverage dan Kebijakan Dividen berdasarkan Siklus Hidup Perusahaan pada Saham LQ45. INA-Rxiv.

Riyanto, Bambang. 2008.Dasar dasar Pembelajaran Perusahaan. BPPE. Yogyakarta.

Setiyawan Indra. 2014. Pengaruh Current Ratio, Inventory Turnover, Time Interest Earned dan Return on Equity Terhadap Harga Saham Pada Perusahaan Manufaktur Sektor Barang Konsumsi Yang Terdaftar di Bursa Efek Indonesia Periode 20192012.Jurnal Nominal / Volume III Nomor 1 / Tahun 2014.

Sugiyono, 2008, Statistika untuk Penelitian, CV Alvabeta. Bandung

Suhartono, \& Yusra, I. (2019). Analisis perbandingan kinerja keuangan bank konvensional dengan bank syariah yang terdaftar di BEI. INARxiv, 1-9.

Weston, J.Fred. \& Eugene F Brigham, 2010. Dasardasar manajemen Keuangan. Jakarta: Erlangga.

Yudhistira, Yayat dkk. 2012. Pengaruh Tingkat Likuiditas, Solvabilitas dan Aktivitas terhadap Profitabilitas Pada Perusahaan Manufaktur Yang Terdaftar Di Bursa Efek Indonesia. Jumal 
Pro Bisnis Vol. 5 No.1 Februari 2012.

Yusra, I. (2014). Analisis Return dan Likuiditas Saham Sebelum dan Sesudah Pengumuman Right Issue di Bursa Efek Indonesia. Jurnal Riset Manajemen Dan Akuntansi, 1(2), 150-163.

Yusra, I. (2016). Pertumbuhan Aktiva Produktif, dana Pihak Ketiga, dan Profitabilitas: Studi Empiris di BUrsa Efek Indonesia. Jurnal KBP, 03(02), 157-164.

Yusuf, D., \& Yusra, I. (2019). Faktor-faktor yang mempengaruhi struktur modal perusahaan. INA-Rxiv. 